\section{Biological weapons research opposed}

\section{Washington}

A NEW campaign against the military use of biomedical research was launched in the United States last week with the publication of a pledge signed by 500 prominent researchers.

The pledge, which commits signatories "not to engage knowingly in research and teaching that will further the development of biological or chemical weapons", is the work of the Committee for Responsible Genetics (CRG)*, a Boston-based pressure group.

CRG hopes that the existence of the pledge will help stiffen scientists' resolve not to take money for US Department of Defense biological research projects. More money has been on offer since the Reagan administration quadrupled the budget of the Biological Defense Program between 1983 and 1986.

Both the United States and the Soviet Union are signatories of the Biological Weapons Convention of 1972 , which bans the research development, stockpiling and use of biological weapons. But the Reagan Administration has revived a programme which had been cut by President Richard Nixon in 1969.

According to Richard Novick, director of the Public Health Research Institute in New York and a member of CRG's advisory board, the reasons Nixon decided to abandon biological weapons research remain sound. Biological weapons have no strategic or tactical value in a conflict between the major powers because their spread cannot be effectively controlled. Any use by one side would be quickly detectable and, if threatening, could provoke a nuclear response from the other side.

Biological weapons make military sense only in covert operations against thirdworld countries, he says. Water supplies could be contaminated with pathogenic micro-organisms and crops destroyed by release of pests. Third-world countries do not have the resources to prove that biological warfare is being used against them.

Any defensive research by the United States always runs the risk of being seen as preparation for offensive operations and could trigger an arms race, according to Jonathan King, professor of molecular biology at MIT and a CRG board member. And there is the additional risk of an accident. At the Dugway Proving Ground, Utah, which the Reagan administration is planning to reopen as an aerosol test facility (see Nature 333, 106, 1988), thousands of sheep died in the 1970s when the wind direction changed during a nerve gas test.

Alun Anderson

"Copies of the pledge are available for signing from CRG, 186A South St, Boston, MA 02111-2701.

\title{
ABRC calls for more money to boost science
}

\section{London}

THE British government's advisers on the science budget are asking for more money to continue restructuring academic science and to pursue new scientific opportunities. In a report to the Secretary of State for Education and Science, issued last week, the Advisory Board for the Research Councils (ABRC) calls for an extra $£ 97$ million in $1989-90$ and an extra $£ 131$ million and $£ 151$ million in the subsequent years. Present spending plans call for $£ 730$ million for $1989-90$, rising to $£ 750$ million in 1991-92, implying a reduction of at least 3 per cent over the next three years after allowing for inflation.

Last year, ABRC asked for $£ 130$ million for 1989-90 and £160 million for the following year, but won increases of only $£ 65$ million and $£ 48$ million for those years. The board now says that was insufficient, either to allow for the reshaping of the science base or to avert a reduction in the amount of research.

Recent data on scientific publications and citation indicate that Britain's share of world scientific output and its influence are declining, says the report, at a time when industry is becoming increasingly science-dependent. Sir David Phillips, chairman of the board, says that although industry should pay for applied research and development, public support is vital to its underpinning of basic science.

Of the total estimated cost of restructuring of $£ 179$ million over the next three years, $£ 105$ million will be for setting up 30 interdisciplinary research centres. The remainder would aid faster restructuring of the research councils to make them more efficient and effective.

An extra $£ 200$ million is needed over the same period, says ABRC, to grasp a range of new scientific opportunities in areas including computer science, quantum optics, the human genome and atmosphere and marine pollution. The remainder would go towards relieving manpower problems, buying scientific equipment and giving increased support to high-quality grant applications. Phillips said the shortage of manpower in research is "absolutely frightening".

Fears over manpower problems were reinforced last week with the publication of a survey of the destination of graduates, by the Association of Graduate Careers Advisory Services. It showed that, though the market for graduate employment is booming, there was a fall last year in the proportion of graduates going into science and engineering research and development. From a peak of 17.4 per cent in 1984 , the figure fell to only 14.5 per cent last year.
ABRC stresses that money earmarked by the government for special cases should not divert the finances of the research councils. The board says it will need an extra $£ 42$ million over the next three years to meet the costs of four programmes the government is at present discussing: contributions to the European particle physics laboratory, CERN; the British Geological Survey; the Medical Research Council's AIDS programme and the British Antarctic Survey. Christine McGourty

\section{Science advice}

\section{London}

BritaIN's Parliamentary and Scientific Committee is setting up a new body to provide members of parliament with inpendent scientific advice on policy issues. The advisory board to the new body, called the Parliamentary Science Foundation (PSF), met for the first time last week

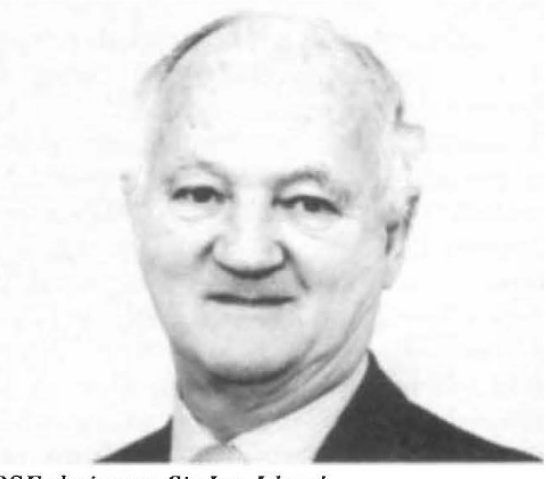

PSF chairman Sir Ian Lloyd.

under its chairman Sir Ian Lloyd to discuss the selection of a director, who it is hoped will be in post by December.

The board says an independent advisory board is vital if MPs are to make informed judgements in areas of public policy influenced by science. Lloyd says that at present MPs risk being the victims of lobbying by interested parties, and are unable to arbitrate between differing scientific judgements.

The new body is to be modelled primarily on the United States Congressional Office of Technology Assessment, which has a full-time staff of 140 and a budget of $\$ 17$ million. But Britain's version will be somewhat smaller, costing about £2 million a year, says Lloyd. So far, the board has raised $£ 177,000$ from companies, scientific institutions, universities and individual donations.

When PSF is granted charitable status, a major national appeal will be launched, and parliament will be asked to match the support pledged from donations. The board hopes the new body will be in operation by the end of 1989 . Christine McGourty 